\title{
FAKTOR-FAKTOR YANG MEMEPENGARUHI POTENSI PUSAT KEGIATAN EKONOMI DI KAWASAN PESISIR KECAMATAN JANGKA KABUPATEN BIREUEN
}

\author{
Andria Zulfa ${ }^{\mathrm{a}^{*}}$, Lena Fitri ${ }^{\mathrm{a}^{*}}$ \\ ${ }^{a}$ Fakultas Ekonomi dan Bisnis Universitas Malikussaleh \\ *Corresponding author: andriazulfa@unimal.ac.id \\ *lena.fitri1996@gmail.com
}

\section{A R T I CLE IN F ORMATION}

Keywords:

Human Resources, Natural Resources, Capital, Technology and Potential
A B S T R A C T

- The purpose of this study is to find out and analyze whether Human Resources, Natural Resources, Capital and Technology have an influence on the Potential of Economic Activities in Jangka Districts in Bireuen Indonesia. The location of this study is in two villages, namely the Mosque Jangka and KetapangJangka. The sample in this study is the community in the two villages with a sample of 177. From the results of the study that the potential has a close and positive relationship to the variables of Human Resources, Natural Resources, Capital and Technology. The test results show that Human Resources, Natural Resources, Capital and Technology are factors that together influence the Potential of Economic Activities in the Jangka District in Bireuen Indonesia. The Independent Variable that most dominantly influences the Potential of Economic Activities in the Jangka District is the Capital Variable.

\section{PENDAHULUAN}

Masyarakat pesisir adalah masyarakat yang tinggal dan menetap di daerah pesisir. Wilayah ini adalah wilayah yang di tandai sebagai tempat perpindahan antara wilayah darat dan laut (Dahuri, 2001). Di wilayahini, sebagian besar masyarakatnya adalah untuk memenuhi kebutuhan sehari-hari dari mengelola sumber daya daya laut, baik secara langsung maupun tidak langsung. Oleh karena itu, dari segi mata pencaharian masyarakat dari kawasan pesisir tersusun dari kelompokkelompok masyarakat yang beragam seperti nelayan, petambak, pedagangang ikan, pemilik toko, serta pelaku industri kecil dan menengah pengolahan hasil tangkap.

Di daerah pesisir kecamatan jangak ini kebanyakan penduduknya bekerja menangkap ikan, sekelompok masyarakat nelayan merupakan unsur terpenting bagi eksistensi masyarakat pesisir. Para nelayan mempunyai peran terpenting dalam mendorong kegiatan ekonomi wilayah dan pembentukan stuktur budaya bagi masyarakat pesisir. Meskipun para nelayan mempunyai peran sosial yang penting, kelompok syarakat yang lain juga mendukung penuh aktivitas sosial ekonomi masyarakat.

Fenomena yang terjadi di kawasan pesisir Kecamatan Jangka Kabupaten Bireuen adalah potensi sumberdaya alam yang besar dan melimpah saat ini belum mampu berkontribusi terhadap pengembangan perekonomian sebagian masyarakat.Untuk itu, maka membutuhkan suatu strategi peningkatanaktivitas masyarakat untuk memberdayakan mereka dalam meningkatkan pendapatan agar lebih berperan dalam lingkup lokal, regional, maupun nasional.Kabupaten Bireuen merupakan salah satu dari 23 kabupaten/kota yang ada di Provinsi Aceh. Secara geografis letak Kabupaten Bireuen sangat strategis karena berada pada jalur lalu lintas Banda Aceh Medan.Batas wilayah Sebelah Utara dengan Selat Malaka, sebelah Selatan dengan Kabupaten Bener Meriah dan Aceh Tengah, sebelah Barat dengan Kabupaten Pidie Jaya dan Pidie dan Sebelah 
Timur dengan Kabupaten Aceh Utara. Luas wilayah Kabupaten Bireuen seluas $1.901,21 \mathrm{Km}^{2}$ atau $190.121 \mathrm{Ha}$ daratan dan laut seluas 503,70 $\mathrm{Km}^{2}$. Secara administratif Kabupaten Bireuen memilik 17 (tujuh belas) kecamatan, 69 (enam puluh sembilan) kemukiman dan 609 desa/gampong. 11 Kecamatan merupakan kecamatan pesisir dengan jumlah desa pesisir sebanyak 114 desa. Potensi sumberdaya kelautan dan perikanan cukup besar. Luas existing tambak $4.945 \mathrm{Ha}$, kolam 90,5 ha dan perairan lainnya dan sawah berpengairan teknis merupakan potensi yang besar untuk dikembangkan perikanan budidaya.

Kondisi Demografis Kabupaten Bireuen Berdasarkan survey pada Tahun 2013 menunjukan bahwa jumlah Penduduk Kabupaten Bireuen mencapai 450.544 jiwa, terdiri dari 222.821 jiwa laki-laki dan 227.723 jiwa perempuan. Untuk lebih rinci dapat dilihat dalam tabel di bawah ini :

\section{Table 1}

Data Tabulasi Jumlah Penduduk Kabupaten Bireun

\begin{tabular}{|l|l|l|l|l|l|}
\hline No & Kecamatan & $\begin{array}{l}\text { Jumlah } \\
\text { Penduduk } \\
\text { Jiwa }\end{array}$ & $\begin{array}{l}\text { Jumlah } \\
\text { Kepala } \\
\text { Keluarga }\end{array}$ & $\begin{array}{l}\text { Laki- } \\
\text { laki }\end{array}$ & Pr \\
\hline 1 & Samalanga & 26.916 & 7.003 & 13.364 & 13.552 \\
\hline 2 & $\begin{array}{l}\text { Simpang } \\
\text { Mamplam }\end{array}$ & 27.685 & 7.119 & 13.964 & 13.721 \\
\hline 3 & Pandrah & 9.209 & 2.465 & 45.37 & 46.72 \\
\hline 4 & Jeunib & 25.350 & 67.69 & 12.556 & 12.794 \\
\hline 5 & Peulimbang & 12.111 & 3.139 & 59.87 & 61.24 \\
\hline 6 & Peudada & 27.980 & 7.635 & 13.812 & 14.168 \\
\hline 7 & Juli & 33.037 & 8.578 & 16.451 & 16.586 \\
\hline 8 & Jeumpa & 36.667 & 9.318 & 18.358 & 18.309 \\
\hline 9 & Kota Juang & 56.263 & 14.606 & 28.140 & 28.123 \\
\hline 10 & Kuala & 19.487 & 5.072 & 9.551 & 99.36 \\
\hline 11 & Jangka & 29.511 & 7.326 & 14.520 & 14.991 \\
\hline 12 & Peusangan & 54.679 & 14.162 & 26.834 & 27.845 \\
\hline 13 & $\begin{array}{l}\text { Peusangan } \\
\text { Selatan }\end{array}$ & 15.482 & 4.191 & 7.604 & 78.78 \\
\hline 14 & $\begin{array}{l}\text { Peusangan } \\
\text { Sb.Krueng }\end{array}$ & 12.328 & 3.326 & 6.026 & 63.02 \\
\hline 15 & Makmur & 15.842 & 3.986 & 7.764 & 8.078 \\
\hline 16 & Gandapura & 24.352 & 6.461 & 11.807 & 12.545 \\
\hline 17 & Kuta Blang & 23.645 & 6.094 & 11.546 & 12.099 \\
\hline & JUMLAH & $\mathbf{4 5 0 . 5 4 4}$ & $\mathbf{1 1 7 . 2 5 0}$ & $\mathbf{2 2 2 . 8 2 1}$ & $\mathbf{2 2 7 . 7 2 3}$ \\
\hline
\end{tabular}

Dari beberapa kecamatan yang dekat dengan pesisir penulis memilih kecamatan jangka untuk menjadi objek penelitiannya. Di karenakan Jangka merupakan salah satu Kecamatan di Kabupaten Bireuen, Propinsi Aceh, Indonesia. Kecamatan Jangak merupakan hasil pemekaran dari Kecamatan Peusangan. Sebahagian besar penduduknya bekerja sebagai petani dan nelayan.
Kecamatan Jangaka merupakan salah satu Kecamatan yang menghasilkan ikan untuk Kabupaten Bireuen.

Usaha budidaya udang merupakan salah satu sumber pendapatan masayarakat kecamatan jangka dan melibatkan petani tambak dalam jumlah besar. Dengan adanya beberapa faktor pembatas pada tambak, maka produktivitas budidaya udang menjadi rendah. Keterbatasn ini disebabkan kurangnya pengetahuan dan keterampilan serta modal untuk membiayai penerapan teknologi budidaya tambak yang dianjurkan. Dengan melalui penyuluhan secara intensif serta di barengi dengan pengadaan sarana penyuluhan yang memadai antara lain dengan di bangunnya tambak-tambak percontohan, balai penyuluhan perikanan serta ditunjang permodalan dengan penyediaan fasilitas- fasilitas yang di butuhakan petani tambang udang di kecamatan jangka. Dengan melaksanakan intensifikasitambak, selain meningkatkan pendapatan petani tambak juga akan memperluas lapangan kerja.

\section{Tabel 2}

\section{Hasil Observasi Awal}

\begin{tabular}{|l|l|l|l|l|l|}
\hline \multirow{2}{*}{ No } & \multirow{2}{*}{ Desa } & \multirow{2}{*}{$\begin{array}{l}\text { Jumlah } \\
\text { KK }\end{array}$} & $\begin{array}{l}\text { Jumlah Penduduk } \\
\text {-laki }\end{array}$ & perempuan & Nelayan \\
\hline 1 & $\begin{array}{l}\text { Jangka } \\
\text { Mesjid }\end{array}$ & 310 & 485 & 510 & 180 \\
\hline 2 & $\begin{array}{l}\text { Jangka } \\
\text { Ketapang }\end{array}$ & 230 & 376 & 446 & 139 \\
\hline
\end{tabular}

Sumber: Data Observai 2018

Berdasarkan hasil observasi awal dapat kita lihat bahwa jumlah nelayan di desa jangka mesjid lebih banyak dari pada jumlah nelayan di desa jangka ketapang. Berdasarkan latar belakan tersebut, maka penulis tertarik untuk melakukan penelitian dengan judul “ Faktor-faktor yang Mempengaruhi Potensi Pusat Kegiatan Ekonomi di Kawasan Pesisir Kecamatan Jangka Kabupaaten Bireuen".

Tujuan penelitian ini adalah:

1. Untukmengetahui pengaruh sumber daya manusia terhadap potensi pusat kegiatan ekonomi di kawasan pesisir Kecamatan Jangka Kabupaten Bireuen

2. Untukmengetahui pengaruh sumber daya alam terhadap potensi pusat kegiatan ekonomi di kawasan pesisir Kecamatan Jangka Kabupaten Bireuen 
3. Untukmengetahui pengaruh pemodalan terhadap potensipusat kegiatan ekonomi di kawasan pesisir Kecamatan Jangka Kabupaten Bireuen

4. Untukmengetahui pengaruh teknologi penangkap ikan terhadap potensi pusat kegiatan ekonomi di kawasan pesisir Kecamatan Jangka Kabupaten Bireuen

\section{LANDASAN TEORITIS}

\section{PengertianWilayah Pesisir}

Daerah pesisir adalah daerah pertemuan atara darat dan laut, dengan batas darat yang meliputi bagian daratan, baik yang kering maupun yang terendam air yang masih mendapat pengaruh dari sifat-sifat laut, seperti pasang surut dan angin laut. Bagian laut, perairan pesisir mencakup bagian batas terluas dari daerah paparan benua yang masih dipengaruhi oleh proses-proses alami yang terjadi di darat, seperti sedimentasi dan aliran air tawar. Kawasan pesisir dikenal ssebagai ekosistem perairan yang memiliki potensi sumber daya yang sangat besar. Wilayah tersebut telah banyak dimanfaatkan dan dan memberikan manfaat yang sangat berarti untuk penigkatan taraf hidup masyarakat di kawasan pesisir dan juga sebagai penghasil pendapatan daerah yang sangat penting.salah satu potensi kawasan, yaitu sebagai pengembangan kawasan parawisata (Fauzi, 2009).

\section{Definisi Ekonomi Masyarakat Pesisir}

Dalam pengusahaan perairan pesisir, menurut (Suseno, 2001) terdapat beberapa aspek yang perlu diperhatikan, yaitu aspek sosial, perikanan, jasa-jasalingkungan, dan keseimbangan lingkungan hidup. Keseimbangan aspek ekonomi, sosialdan lingkungan hidup dalam proses pembangunan adalah prinsip yang senantiasa harusmenjadi dasar utama bagi seluruh stakeholder. Secara umum prinsip pengelolaan sumberdaya meliputi empat hal, yaitu 1) prinsip kehati-hatian. Hal ini termasuk dalam Code ofConduct for Responsible Nature 1995, yang menyebutkan negara harus memberlakukanpendekatan yang bersifat kehatihatian secara luas demi konservasi, pengelolaan, danpengusahaan sumber daya hayati guna melindungi dan mengawetkan lingkungannya, 2)prinsip tanggung Jawab, pengelolaan yang bertanggung jawab tidak memperbolehkanhasil tangkapan melebihi jumlah potensi lestari yang boleh ditangkap, 3) prinsipKeterpaduan, yaitu keterpaduan antara pemerintah pusat, pemerintah daerah, duniausaha dan masyarakat dalam proses perencanaan, pelaksanaan dan pengawasan dalam pengelolaan dan pemanfaatan sumber daya, 4) prinsip Berkelanjutan yaitu konsep pembangunan berkelanjutan adalah pembangunan yang mengintegrasikan komponen ekologi, ekonomi dan sosial. Setiap komponen itu saling berhubungan dalam satu sistem yang dipicu kekuatan dan tujuan.

\section{Faktor-faktor yang Mempengaruhi Potensi Pusat Kegiatan Ekonomidi Kawasan Pesisir}

Jenis penelitian yang di sajikan adalah metode deskriptif kuantitatif, yang diteliti dengan melakukan pendataan pada masyarakat dengan membagikan kuisioner berdasarkan variabelvariabel hasil tinjauan kepustakaan untuk mengudentifiasi faktor-faktor apa saja yang berpengaruh terhadap perkembangan sektor perikanan. Bedasarkan hasil kepustakaan dan surve tahap awal didapatkan variabel penelitian antara lain: pendapatan msyarakat, tingkat pertumbuhan lapangan kerja, tingkat penentuan kebutuhan dasar, tingkat harga diri, tingkat kemampuan memilih kebutuha hidup, tingkat pemenuhan jumlah angkatan kerja dan juga keterkaitan.

\section{Kualitas Sumber Daya Manusia}

Beberapa ahli memberikan pengertian kualitas sumber daya manusia. Sumber daya manusia adalah suatu keahlian yang berasal dari manusia itu sendiri. Keahlian yang bersumber dari manusia itu sendiri dapat juga di sebut sebagai tenaga atau kekuatan (energi atau power). Beberapa hal yang harus utuh dan berkualitas, dapat dilihat dari aspek yang relatif mudah sampai dengan aspek yang relatif rumit.

Sesuai dengan masalah yang akan i jelskan, peneliti mengajukan teori kualitas sumber daya manusia yang di jelaskan oleh (Sedarmayanti, 2001) dalam buku "Sumber Daya Manusia dan Produktivitas Kerja", mengemukakan bahwa Kualitas merupakan suatu ukuran yang menyatakan seberapa jauh telah dipenuhi berbagai persyaratan, spesifikasi, dan harapan.

\section{Kualitas Sumber Daya Alam}


Sumber daya kelautan merupakan sumber daya yang meliputi, wilayah yang luas yang mencakup kehidupan laut (floran dan fauna, mulai dari organisme mikroskopis) mulai dari perairan dalam sampai ke daerah pasang surut dipantai dataran tinggi dan daerah muara yang luas. Kebanyakan masyarakat memanfaatkan dan berinteraksi dengan lingkungan laut mulai dari pelaut, nelayan komersial, pemanen kerang, ilmuan dan lain-lain. Dan banyak juga di gunakan untuk berbagai kegiatan baik rekreasi, penelitian , industri, dan juga kegiatan lain yang bersifat komersial.

Sumber daya alam merupakan potensi alam yang terdapat di bumi ini yang memberi manfaat bagi kehidupan masyarakat. Sumber daya alam dapat berupa benda hidup (unsur-unsur hayati), yaitu hewan dan tumbuhan. Sumber daya alam ada juga yang bersifat benda mati (non hayati), seperti tanah, udara, air, bahan galian dan juga barang tambang. Selain itu terdapat pula kekuatankekuatan alam menghasilkan tenaga atau energi. Contohnya, panas bumi, energi mata hari, kekuatan air, dan tenaga angin. Segala sesuatu yang ada di alam yang dinilai memiliki nilai guna untuk memenuhi kebutuhan sehingga tercipta kesejahteraan hidup manusia tersebut dinamakan sumber daya alam.

\section{Permodalan}

Masalah kemiskinan nelayan merupakan masalah yang bersifat multi dimensi sehingga untuk menyelesaikannya diperlukan sebuah solusi yang menyeluruh, dan bukan solusi secara parsial. Untuk kita, terlebih dahulu harus diketahui akar masalah yang menjadi penyebab terjadinya kemiskinan nelayan.Secara umum, kemiskinan masyarakat pesisir ditengarai disebabkan oleh tidak terpenuhinya hak-hak dasar masyarakat, antara lain kebutuhan akan pangan, kesehatan, pendidikan, pekerjaan, inftastruktur. Di samping itu, kurangnya kesempatan berusaha, kurangnya akses terhadap informasi, teknologi dan permodalan, budaya dan gaya hidup yang cenderung boros, menyebabkan posisi tawar masyarakat miskin semakin lemah. Pada saat yang sama, kebijakan Pemerintah selama ini kurang berpihak pada masyarakat pesisir sebagat salah satu pemangku kepentingan di wilayah pesisir.

\section{Teknologi}

Analisis terhadap komoditi unggulan telah dilakukan dengan memperoleh jenis komoditinya dan potensi yang masih memiliki peluang pengembangannya pada masa yang akan datang. Selanjutnya dapat dilakukan analisis terhadap jenis teknologi yang memungkinkan digunakan dalam mendukung pemanfaatan sumberdaya ikan dominan di Provinsi Sumatera Selatan. Menurut (Monitja, 2000), pemilihan suatu teknologi penangkapan ikan yang tepat untuk diterapkan dalam pengembangan perikanan tangkap perlu mempertimbangkan : (1) teknologi yang ramah lingkungan, (2) teknologi yang secara teknis dan ekonomis menguntungkan, dan (3) teknologi yang berkelanjutan (Nurani, 2002).

\section{Potensi}

Potensi adalah serangkaian kemampuan, kesanggupan, kekuatan, ataupun daya yang mempunyai kemungkinan untuk bisa dikembangkan lagi menjadi bentuk yang lebih besar (Majdi, 2007). Potensi dalam kegiatan bidang ekonomi berarti memiliki arti pengertian sesuatu yang dapat dikembangkan atau dapat ditingkatkan pemanfaatan nilainya. Jika kata ini dikaitkan dengan sumberdaya alam, makaberartimenggalinilaimanfaat SDA yang lebih mengarah kepada kegiatan bentuk ekonomi. Sebagai contohnya potensi dalam kegiatan bentuk ekonomi sumberdaya perairan, berarti kata potensi disini memiliki arti bahwa kita berusaha meningkatkan atau mengembangkan potensi sumber daya perairan agar memiliki nilai guna pada bidang ekonomi.

\section{Potensi Laut}

Untuk menggali potensi ini maka dibutuhkan aktivitas atau kegiatan dalam bentuk ekonomi yang bisa menggali dan meningkatkannya. Sebagai contohya itu untuk meningkatkan potensi sumberdaya perairan maka harus ada kegiatan yang kita lakukan untuk meningkatkan nilai manfaatnya. Misalnya dengan melakukan kegiatan budidaya ikan kerambah, kegiatan budidaya rumput laut serta kegiatan lainnya dimana bisa meningkat kan nilai ekonomi dari SDA tersebut.

\section{Potensi Darat}

$\begin{array}{ccc}\text { Dalam } & \text { usaha budidaya udang selalu } \\ \text { melibatkan } & \text { proses produksi, kegiatan }\end{array}$ mendapatkan sarana produksi, modal serta pemasaran hasilnya, untuk itu produsen dituntut 
untuk mengetahui dengan jelas beberapa hal yang berkaitan dengan usahanya, seperti faktor produksi, pengelolaan budidaya yang baik dan efisien, pengetahuan dengan biologinya, informasi yang jelas tentang peserta cabang sumber yang ada agar bisnis pertambakkan dapat dikembangkan. Ketersediaan pakan dalam jumlah yang cukup, tepat waktu dan bernilai gizi tinggi baik merupakan faktor yang sangat penting dalam kegiatan usaha udang. Sumber makanan bagi udang peliharan ditambak berasal dari pakan alami dan bantuan, oleh jumlah pakan yang alami dalam tambak sangat terbatas dan kurang memadai maka akan tercapai laju pertumbuhan yang baik. Perencanaan akan berjalan dengan baik apabila disertai dengan pengawasan, karena perencanaan tanpa pengawasan hasilnya tidak seperti yang diharapkan akan tetapi dalam hal ini pengawasan bukan hanya mengawasi tetapi membandingkan hasil produksi dengan rencana yang akan dicapai serta hasil pekerjaan yang tidak sesuai dengan standar yang harus dilakukan penyelidikan apa yang menyebabkannya, lalu diusahakan perbaikanperbaikan agar penyimpangan tersebut dapat diatasi.

\section{Hipotesis}

Berdasarkan permasalahan pokok dan tinjauan pustaka diatas, maka hipotesis penelitian ini adalah sebagai berikut:

H1: Sumber daya manusia berpengaruh terhadap potensi pusat kegitan ekonomi masyarakat di kawasan pesisir Kecamatan Jangka Kabupaten Bireuen.

H2: $\quad$ Sumber daya alam berpengaruh terhadap potensi pusat kegitan ekonomi masyarakat di kawasan pesisir Kecamatan Jangka Kabupaten Bireuen.

H3: Permodalan berpengaruh terhadap potensi pusat kegitan ekonomi masyarakat di kawasan pesisir Kecamatan Jangka Kabupaten Bireuen.

H4: Teknologi berpengaruh terhadap potensi pusat kegitan ekonomi masyarakat di kawasan pesisir Kecamatan Jangka Kabupaten Bireuen

\section{METODE PENELITIAN}

\section{Lokasi dan Objek Penelitian}

Lokasi penelitian ini saya lakukan di Kecamatan Jangka Kabupaten Bireuen yang menyebar di 2 (dua) desa yaitu: jangka mesjid dan desa jangka ketapang. Daerah ini saya ini saya pilih dengan sengaja, karena desa tersebut tergolong dalam kawasan pesisir, mata pencaharian dan pekerjaan penduduknya mayoritas nelayan, penetapan secara sengaja pada lokasi penelitian si desa jangka mesjid dan jangka ketapang di dasarkan pada indikator yang relevan, yaitu daerah yang termasuk daerah pantai. Desa yang terbanyak penduduknya sebagai nelayan.sdangkan yang menjadi objek dalam penelitian ini adalah seluruh masyarakat yang tinggal dan menetap di daerah pesisir Kecamatan Jangka Kabupaten Bireuen.

\section{Definisi Operasional Variabel}

Variabel yang digunakan terdiri dari variabel Terikat (Dependen) yaitu Potensidan variabel bebas (independen) yaitu sumber daya manusia, sumber daya alam, lemahnya permodalan, teknologi penangkap ikan . Definisi operasional variabel ini dilakukan untukmemberikan batasan dan ruang lingkup terhadap variabel yang diteliti. Adapun pengertian dan indikator dari variabel-variabel serta skala yang dipergunakan dalam penelitian ini adaah sebagai berikut:

1. Potensi (Y)

Suatu kemampuan kesanggupan, kekuatan ataupun daya yang mempunyai kemungkinan untuk bisa berkembang (Diukur dengan skala likert).

2. Sumber Daya Alam (X1)

Sumber daya alam (SDA) ialah sesuatu yang dapat dimanfaatkan untuk berbagai keperluan dan kebutuhan hidup masyarakat agar bisa lebih sejahtera. Sumber daya alam bisa terdapat di mana saja seperti tanah, air, udara, dan lainnya(Diukur dengan skala likert).

3. Sumber Daya Manusia (X2)

Sumber daya manusia (SDM) merupakan salah satu faktor yang sangat penting sehingga tidak dapat dilepaskan dari sebuah organisasi, baik institusi ataupun perusahaan. SDM juga merupakan jalan menuju perkembanga suatu perusahaan. Pada dasarnya, SDM merupakan tenaga manusia yang dipekerjakan di sebuah organisasi atau perusahaan sebagai penggerak untuk mencapai tujuan dari organisasi itu sendiri (Diukur denga skala likert).

\section{Permodalan (X3)}


Modal adalah sejumlah uang atau barang yang digunakan sebagai dasar untuk melaksanakan suatu pekerjaan(Diukur dengan skala likert).

\section{Teknologi (X4)}

Teknologi penagkap ikan merupakan suatu hal yang sangat penting dalam kehidupan nelayan dalam melakukan aktifitasnya (Diukur dengan skala likert).

\section{HASIL PENELITIAN DAN PEMBAHASAN}

\section{Uji Normalitas}

Uji normalitas bertujuan untuk menguji apakah dalam model regresi variabel terikat (independent variable) dan variabel bebas (dependent variable) memiliki distribusi normal atau tidak. Salah satu cara termudah untuk melihat normalitas residual adalah dengan melihat normal probability plot. Pada prinsipnya normalitas dapat dideteksi dengan melihat penyebaran data (titik) pada sumbu diagonal dari grafik. Dasar pengambilan keputusan menurut (Ghozali, 2011)adalah sebagai berikut:

1. Jika data menyebar di sekitar garis diagonal dan mengikuti arah garis diagonal atau grafik histogramnya menunjukkan pola distribusi normal, maka model regresi memenuhi asumsi normalitas.

2. Jika data menyebar jauh dari garis diagonal dan tidak mengikuti arah garis diagonal atau grafik histogram tidak menunjukkan pola distribusi normal, maka model regresi tidak memenuhi asumi normalitas.

Berikut ini merupakan hasil olahan data dari uji normalitas, yang dapat dilihat pada gambar grafik 1 dibawah ini :

Normal P-P Plot of Regression Standardized Residual

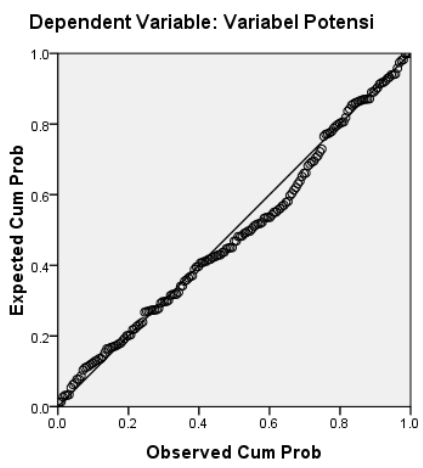

Gambar 1

Normal P-Plot

Dengan melihat tampilan grafik normal plot dapat disimpulkan bahwa model regresi memenuhi asumsi normalitas karena pada grafik normal plot terlihat titik-titik menyebar disekitar garis diagonal.Uji normalitas juga bisa di uji dengan metode uji Kolmogorov-smirnov. Berikut ini adalah hasil uji normalitas dengan metode uji Kolmogorov-smirnov dengan menggunakan program SPSS

Table 3

One-Sample Kolmogorov-Smirnov Test

\begin{tabular}{|ll|r|}
\hline & & \multicolumn{2}{|c|}{$\begin{array}{c}\text { Unstandardized } \\
\text { Residual }\end{array}$} \\
\hline N & Mean & 177 \\
Normal Parameters & \\
& Std. & .0000000 \\
Most Extreme & Deviation & 1.72135943 \\
Differences & Absolute & .071 \\
& Positive & .071 \\
Kolmogorov-Smirnov Z & Negative & -.032 \\
Asymp. Sig. (2-tailed) & & .940 \\
Asym & .340 \\
\hline
\end{tabular}

Menurut (Santoso, 2008)suatu data dapat dikatakan telah berdistribusi normal apabila skor signifikansi Kolmogorov-smirnov lebih besar dari nilai signifikansinya sebesar 0.05. pada skor signifikan dari data di atas sebesar 0.340 sehingga dapat disimpulkan bahwa data yang ada telah berdistribusi dengan normal karena skor signifikansinya lebih dari 0.05 .

\section{Uji Normalitas}

Untuk mengetahui terdapatnya heteroskedastisitas, peneliti melakukan dengan melihat grafik plot antara nilai prediksi variable terikat (ZPRED) dengan residualnya (SRESID). Untuk mengetahui ada tidaknya heteroskedastisitas dapat dilakukan dengan melihat ada tidaknya pola tertentu pada grafik scatterplot antara SRESID dan ZPRED dimana sumbu $\mathrm{Y}$ adalah $\mathrm{Y}$ yang telah diprediksi, dan sumbu $\mathrm{X}$ adalah residual (Y prediksi- $\mathrm{Y}$ sesungguhnya) yang telah di studentized. Dari hasil olah data, dapat dilihat hasil uji heteroskedastisitas sebagai berikut: 


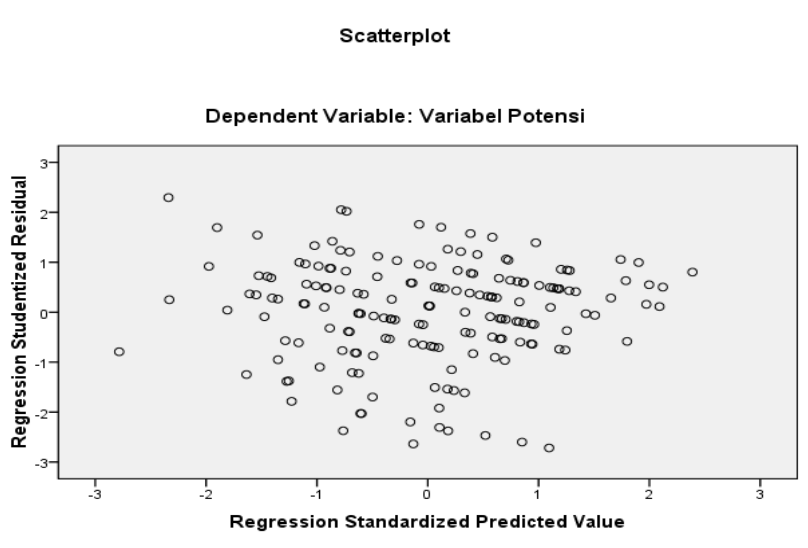

Gambar 2 Scatterplot

Berdasarkan grafik scatterplot terlihat bahwa titik-titik menyebar secara acak serta tersebar baik diatas maupun dibawah angka nol pada sumbu $\mathrm{Y}$ dan grafik plot tidak membentuk pola yang jelas. Hal ini dapat disimpulkan bahwa tidak terjadi heteroskedastisitas pada model regresi, sehingga model regresi layak dipakai untuk memprediksipotensi berdasarkan variabel sumber daya manusia, sumber daya alam, permodalan, dan teknologi.

\section{Uji Multikolinieritas}

Uji Multikolinearitas bertujuan untuk menguji apakah model regresi ditemukan adanya korelasi antar variabel independen. Uji multikolonieritas dilihat dari nilai tolerancedan Variance Inflantion Factor (VIF)(Ghozali, 2009). Untuk mendeteksi adanya problem multikolinearitas, maka dapat dilakukan dengan melihat nilai Tolerance dan Variance Inflation Factor (VIF) serta besaran korelasi antar variabel independen. Regresi yang baik memiliki VIF di sekitar angka 1 (satu) dan mempunyai angka Tolerance mendekati 1 (Santoso, 2008).Apabila nilai VIF kurang dari sepuluh dan nilai Tolerance (T) lebih dari 0,1 dan kurang atau sama dengan 10, berarti tidak terjadi multikolinearitas. Sebaliknya jika diketahui nilai VIF lebih dari sepuluh dan nilai Tolerance (T) kurang dari 0,1 dan lebih dari 10, berarti terjadi multikolinearitas. Maka untuk melihat hasil olah data uji multikolinieritas dapat dilihat pada tabel dibawah ini:

Tabel 4

Uji Multikolinieritas

\begin{tabular}{|l|c|c|}
\hline \multirow{2}{*}{ Model } & \multicolumn{2}{|c|}{ Collinearity Statistic } \\
\cline { 2 - 3 } & Tolerance & VIF \\
\hline $\begin{array}{l}\text { Sumber daya manusia } \\
\text { (X1) }\end{array}$ & .990 & 1.010 \\
\hline
\end{tabular}

\begin{tabular}{|l|c|c|}
\hline $\begin{array}{l}\text { Sumber daya alam } \\
\text { (X2) }\end{array}$ & .979 & 1.021 \\
\hline Permodalan (X3) & .983 & 1.018 \\
\hline Teknologi (X4) & .987 & 1.013 \\
\hline
\end{tabular}

Sumber: Output Data Diolah, 2018.

Berdasarkan Tabel 4.14, dapat dilihat bahwa nilai VIF di sekitar angka 1 (satu) dan mempunyai angka Tolerance mendekati 1 . Hasil olah data diketahui bahwa variabel sumber daya manusia $\left(\mathrm{X}_{1}\right)$ sebesar 1.010, sumber daya alam $\left(\mathrm{X}_{2}\right)$ sebesar 1.021, permodalan $\left(\mathrm{X}_{3}\right)$ sebesar 1.018 dan teknologi $\left(\mathrm{X}_{4}\right)$ sebesar 1.013.

\section{Hasil Analisis Regresi Linier Berganda}

Potensidipengaruhi oleh variabel sumber daya manusia, sumber daya alam, ppermodalan dan teknologi. Hal ini dibuktikan dengan menggunakan analisis regresi yang digunakan untuk menguji pengaruh kedua variabel tersebut terhadap potensi. Berdasarkan hasil estimasi terhadap variabel yang diteliti melalui bantuan dengan program SPSS, maka diperoleh hasil seperti pada tabel dibawah ini:

Tabel 5

Hasil Uji t

\begin{tabular}{|c|c|c|c|c|c|}
\hline \multirow[b]{2}{*}{ Model } & \multicolumn{2}{|c|}{$\begin{array}{l}\text { Unstandardized } \\
\text { Coefficients }\end{array}$} & \multirow{2}{*}{\begin{tabular}{|c|}
$\begin{array}{c}\text { Standardized } \\
\text { Coefficients }\end{array}$ \\
Beta
\end{tabular}} & \multirow[b]{2}{*}{$t$} & \multirow[b]{2}{*}{ Sig. } \\
\hline & B & $\begin{array}{l}\text { Std. } \\
\text { Error }\end{array}$ & & & \\
\hline 1 (Constant) & 5.834 & 2.468 & & 7.364 & .019 \\
\hline $\begin{array}{l}\text { Variabel } \\
\text { SDM }\end{array}$ & .083 & .053 & .095 & 2.561 & .020 \\
\hline $\begin{array}{l}\text { Variabel } \\
\text { SDA }\end{array}$ & .117 & .063 & .114 & 2.860 & .025 \\
\hline $\begin{array}{l}\text { Variabel } \\
\text { Permodalan }\end{array}$ & .485 & .050 & .590 & 9.635 & .000 \\
\hline $\begin{array}{l}\text { Variabel } \\
\text { Teknologi }\end{array}$ & .075 & .059 & .077 & 3.262 & .016 \\
\hline
\end{tabular}

Berdasarkan hasil pengamatan data menunjukkan nilai konstanta 5.834, sumber daya manusia $\left(X_{1}\right) 0.083$, sumber daya alam $\left(X_{2}\right) 0.117$, permodalan $\left(\mathrm{X}_{3}\right) \quad 0.485$ dan teknologi $\left(\mathrm{X}_{4}\right)$ 0.075.Secara persamaan dapat ditulis sebagai berikut:

$$
Y=5.834+0.083 X_{1}+0.117 X_{2}+0.485 X_{3}+0.075 X_{4}+e
$$

Dari formulasi model diatas variabel konstanta ( $\alpha$ ) mempunyai koefisien sebesar 5.834 artinya jika sumber daya manusia ( $\left.\mathrm{X}_{1}\right)$, sumber daya alam $\left(\mathrm{X}_{2}\right)$, permodalan $\left(\mathrm{X}_{3}\right)$, teknologi (X4) jika semua variabeldianggap tetap atau tidak berubah, maka 
nilai koefisien potensi pusat kegiatan ekonomi adalah sebesar 5.834 satu-satuan. Jika koefisien sumber daya manusia (X1) meningkat satu-satuan maka akan meningkatkan potensi pusat kegiatan ekonomi sebesar 0.083 satu-satuan, jika koefisien sumber daya alam (X2) meningkat satu-satuan maka akan meningkatkan potensi pusat kegiatan ekonomi sebesar 0.117 satu-satuan, jika koefisien permodalan (X3) meningkat satu-satuan maka akan meningkatkan potensi pusat ekonomi sebesar 0.485 satu-satuan, dan jik koefisien teknologi $\left(\mathrm{X}_{4}\right)$ mengkiat satu-satuan maka akan meningkatkan potensi pusat kegiatan ekonomi sebesar 0.075 satu-satuan. Apabila faktor sumber daya manusia, sumber daya alam, permodalan dan teknologi ditingkatkan maka potensi juga akan meningkat searah dengan peningkatan masing-masing faktor tersebut.

\section{Koefisien Korelasi Dan Koefisien Determinasi}

Koefisien determinasi ini dimaksudkan untuk mengetahui seberapa besar hubungan variabel independen terhadap variabel dependen.Nilai koefisien determinasi antara nol dan satu. Berikut adalah tabel hasil analisis Korelasi :

Tabel 6

Hasil Analisis Korelasi

\begin{tabular}{|l|l|r|r|r|}
\hline Model & $\mathrm{R}$ & R Square & $\begin{array}{c}\text { Adjusted R } \\
\text { Square }\end{array}$ & $\begin{array}{l}\text { Std. Error of } \\
\text { the Estimate }\end{array}$ \\
\hline 1 & $.802^{\mathrm{a}}$ & .641 & .622 & 1.735 \\
\hline
\end{tabular}

a. Predictors: (Constant), Variabel

Teknologi, Variabel Permodalan,

Variabel SDM, Variabel SDA

b. Dependent Variable:

Variabel Potensi

Dari pengolahan data penelitian diperoleh korelasi (R) sebesar 0.802, ini berarti bahwa hubungan antara variabel sumber daya manusia $\left(\mathrm{X}_{1}\right)$, sumber daya alam $\left(\mathrm{X}_{2}\right)$, permodalan $\left(\mathrm{X}_{3}\right)$ dan teknologi $\left(\mathrm{X}_{4}\right)$ terhadap potensi $(\mathrm{Y})$ sebesar $80.2 \%$, ini bermakna bahwa hubungan yang terjadi antarapotensi dengan sumber daya manusia, sumber daya alam, permodalan dan teknologiadalah erat dan positif.

Nilai koefisien determinasi $\left(\mathrm{R}^{2}\right)$ adalah $\mathrm{R}^{2}$ $=0,641$ atau $64.1 \%$ hal ini menunjukkan bahwa besarnya kemampuan variabel sumber daya manusia, sumber daya alam, permodalan dan teknologisebesar $64.1 \%$, sisanya sebesar $35,9 \%$ dipengaruhi oleh variabel lain yang tidak penulis analisis dalam penelitian ini..

\section{PENUTUP \\ Kesimpulan}

Berdasarkan hasil penelitian yang telah dianalisis di atas, maka dapat diambil kesimpulan sebagai berikut :

1. Sumber daya manusia berpengaruh signifikan terhadap potensi kegiatan ekonomi di kecamatan jangka kabupaten bireuen.

2. Sumber daya alam berpengaruh signifikan terhadap potensi kegiatan ekonomi di kecamatan jangka kabupaten bireuen.

3. Permodalan berpengaruh signifikan terhadap potensi kegiatan ekonomi di kecamatan jangka kabupaten bireuen.

4. Teknologi berpengaruh signifikan terhadap potensi kegiatan ekonomi di kecamatan jangka kabupaten bireuen.

5. Sumber daya manusia, sumber daya alam, permodalan dan teknologi secara bersamasama berpengaruh signifikan terhadap potensi kegiatan ekonomi di kecamatan jangka kabupaten bireuen.

\section{Saran}

Adapun saran-saran yang diharapkan dalam penelitian ini adalah sebagai berikut:

1. Diharapkan kepada masyarakat dari kedua desa lebih memperhatikan masalah sumber daya manusia, sumber daya alam, permodalan serta teknologi sehingga potensi ekonomi di kedua desa tersebut dapat meningkatkan ekonomi serta dapat mengembangkan usaha yang lebih baik kedepannya khususnya hasil laut dan hasil darat.

2. Diharapkan

kepadapemerintahkabupatenBireuenhendakny amemperhatikanlebihbaiklagidansecaramerata terhadappotensi-potensi yang ada di kecamatanJangka agar pemanfaatan sumberdaya yang ada dapat dikelola semaksimal mungkin, serta kedepan menjadi acuan bagi kabupaten lain dalam mengelola sumberdaya sector laut dan darat yang ada di kecamatan angka.

3. Diharapkanpenelitianinidapatmenjadibahanref erensiuntukpenelitianselanjutnyadanpadapene litianselanjutnyadapatmengujiulangpenelitiani nidenganmenambahvariabel-variabel lain yang tidak diteliti dalam penelitian ini, 
sehingga dapat menyempurnakan penelitianpenelitian ini untuk masa datang.

\section{KEPUSTAKAAN}

Ani Yulianti.(2011). Faktor-faktor Yang Berpengaruh Terhadap Audit Delay (Studi Empiris Pada Perusahaan yang Terdaftar di Bursa Efek Indonesia Tahun 2007-2008).Skripsi.Universitas Negeri Yogyakarta

Ari Kunto, (2002), Prosedur Suatu Penelitian; Pendekatan praktek, Edisi Revisi Kelima, Penerbit Rineka Cipta, Jakarta.

Arimoto. T. (2000). Research and Education System of Fishing Technology in Japan. TUF-JSPS International Project. Vol. 8. March 2000. Proceeding the 3 rd JSPS International Seminar on Fisheries sciences in Tropical Area Sustainable Fishing Technology in Asia Towards the 21 st Century. Tokyo University of Fisheries. p 32- 37.

Atmaja, (2010). Buku Lengkap Bahasa Indonesia dan Peribahasa. Jakarta: Pustaka Widyatama.

Aqilah, Z. (2011). Wilayah Pesisir dan Ekosistem Mangrove. http:// zalfaaqilah. wordpress.com/wilayah pesisir dan ekosistem mangrove. Diakses 23 Mei 2011

Bengen, (2002). Ekosistem dan sumberdaya alam pesisir dan laut serta prinsip pengelolaannya. Sinopsis. Pusat Kajian Sumber daya Pesisir dan Lautan. IPB

Budiono, (2004). Statistika Untuk Penelitian.Surakarta: Sebelas Maret university Press

Carlos, C. (2011). Konsep dan Definisi Pengelolaan Wilayah Pesisir dan kelautan.http://carolinacarlos.mhs.upnyk.a c.id/pesisir/konsepdandefinisipengelolaanw ilayahpesisirdankelautan.

Dahuri dkk, (2001). Pengelolaan Sumber daya Wilayah Pesisir dan Lautan Secara Terpadu. PT. Pradnya Paramita. Jakarta.

Dahuri, R., J, Rais, S.P.Ginting dan M.J.Sitepu. (2004). Pengelolaan Sumberdaya Wilayah Pesisir dan Lautan Secara Terpadu.Cetakan Ketiga, Edisi Revisi. PT Pradnya Paramita, jakarta

Dwe Priantno, (2008) dalam finandar (2017). Mandiri Belajar SPSS. Yogyakarta, Mediakom.
Fauzi, Muchamad. (2009). Metode Penelitian Kuantitatif. Edisi Pertama. Walisongo Press. Semarang.

Ghozali,Imam.(2011).Manajemen personaliadanSumberDayaManusia.Lib erti, Yogyakarta.

Hasibuan, Malayu S.P, (2003), Manajemen Sumber Daya Manusia, Edisi Revisi, Bumi Aksara, Jakarta.

Hariandja, Marihot T.E, (2002). Sumber Daya Manusia. Manajemen Jakarta: Grasindo.

Kordi, (2011). Kordi, M.G.H. 2011. Kiat Sukses Budidaya Rumput Laut di laut dan Tambak. ANDI OFFSET. Yogyakarta. $134 \mathrm{Hal}$

Mathis, R.L.\&J.H.Jackson. (2006). Human Resource Management:Manajemen Sumber Daya Manusia. Terjemahan Dian Angelia. Jakarta: Salemba Empat.

Magnis-Suseno, Franz, (2001), Kuasa dan Moral, Gramedia Pustaka Utama, Jakarta.

Majdi, UdoYaminEfendi. (2007). Quranic Quotient. Jakarta: Qultum Media.

Monintja, D. R. (2000). Pemanfaatan Sumberdaya Pesisir dalam Bidang Perikanan Tangkap. Prosiding Pelatihan Pengelolaan Wilayah Pesisir Terpadu. Pusat Kajian Sumber daya Pesisir dan Lautan. Institut Pertanian Bogor. Bogor.

Nugroho., Finandar, (2015). Analis peengaruhJumlahTenagaKerja, Upah Minimum Regional, danPendapatanAlsi Daerah TerhadapPertumbuhan ekonomi Kota LhokseumawePeriode 20082013.UniversitasMalikussaleh.

Nontji, (2002). Laut Nusantara. Cetakan ketiga. Penerbit Djambatan, Jakarta: 367 hal.

Prasetyawan, Ari W. (2011). Faktor - Faktor Yang Mempengaruhi Potensi Produksi Nelayan Di Desa Tasik Agung Kecamatan Rembang Kabupaten Rembang

Paulus, C. (2011). Gambaran Umum Wilayah Pesisir Indonesia. http://chaterina

paulus.blogspot.com/gambar. Diakses 29 April 2011.

Prakoso (2013).PeranTenagaKerja, Modal danTeknologiterhadapPotensiPendapata 
nMasyarakatNelayan di

DesaAsemdoyongKecamatan Taman

KabupatenPemalang

Sarmintohadi. (2002). Seleksi Teknologi

Penangkapan Ikan Karang Berwawasan

Lingkungan di Perairan Pesisir Pulau

Dulah Laut Kepulauan Kei, Kabupaten

Maluku Tenggara. Tesis. Bogor:

Teknologi Kelautan, Program Pascasarjana.

Institut Pertanian Bogor. $128 \mathrm{hlm}$.

Sujarno (2008).AnalisisFaktor-Faktor yang

MempengaruhiPotensiNelayan di

KabupatenLangkat

Sumarsono, Sonny. (2003). Ekonomi Manajemen

Sumber Daya Manusia dan Ketenaga

kerjaan. Jogyakarta : Graha Ilmu.

Sudarmayanti, (2001). Dalam buku sumber daya manusia dan produktifitas kerja

Suegiarto, dahuri et al (2001). Pengelolaan sumberdaya wilayah pesisir dan lautan secara terpadu. PT. Pradnya Paramita, Jakarta.

Sugiono, (2005). Metode Penelitian Bisnis.

Bandung: Alfabeta

Yuliati, Evi. (2009). Analisis Strategi

Pengembangan Usaha Pembenihan Udang

Vaname (Litopenaeus vannamei). Skripsi. IPB. 